\title{
LAS INFAMIAS ESTÉTICAS DE BORGES
}

F. MORALES LOMAS 1

Universidad de Málaga

\begin{abstract}
Resumen
La relación entre la creación libresca, la lectura y la organización de un mundo ha sido siempre motivo de honda atracción en la literatura borgiana. El presente trabajo pretende dar algunas claves de esta tendencia infame en la literatura de Borges y el valor estético de la infamia como instrumento para construir su retórica creadora.
\end{abstract}

Palabras clave: Borges, estética, infamia, siglo XX.

\begin{abstract}
The relationship between the creation bookish, reading and organization of a world has always been a cause for deep attraction in literature borgiana. This paper aims to give some keys to this nefarious trend in the literature of Borges and the aesthetic value of infamy as a tool to build your creative rhetoric.
\end{abstract}

Key words: Borges, aesthetics, infamy, the twentieth century.

\section{Acercamiento estético}

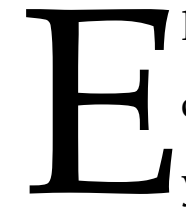

1 principio que sostiene la literatura borgiana es que «la literatura no es otra cosa que un sueño dirigido». La ficción estética y sus galanes procesos nacen y crecen en los sueños, como la existencia de los seres humanos en la imaginación de Dios y de Lucifer. Así lo declara en el Prólogo de El informe Brodie (1970), donde realiza un análisis sintético y expresivo de su estética literaria y, entre otras cosas, observa que con sus cuentos no pretendió sino distraer y conmover. Creo

\footnotetext{
1 Profesor de la Universidad de Málaga. Correo-e: lomas@uma.es. Recibido: 10-12-2008; segunda versión: 14-05-2009.
} 
que estos dos principios, que suscriben muchos escritores entre los que me encuentro, son inherentes al hecho literario, lejos de esa dimensión estética y ética que también posee, al menos para el que esto suscribe. También nos dice que pocos han sido los argumentos que le han hostigado a lo largo del tiempo y, en consecuencia, se autodefine como un escritor monótono temáticamente. Y siempre ha preferido en su obra «la preparación de una expectativa o la de un asombro» y no las sorpresas del estilo barroco o las que deparan un final imprevisto. Se define lingüísticamente en la indefinición porque nunca ha pretendido concentrar su obra en lo que dicen los diccionarios a los que considera reductores de la realidad. Pero sobre todo se ha dejado llevar en la construcción por el principio absoluto de la libertad, de ahí el situar sus obras en lugares lejanos al momento en que escribe que impidan los límites espaciales tanto como la relación sentimental con la causa-efecto.

En consecuencia, sus principios rectores son:

1. El escritor debe elaborar su obra en plena libertad creativa.

2. La literatura debe distraer, entretener o divertir al lector.

3. La literatura debe conmover, emocionar, impresionar al lector.

4. La literatura debe crear expectativas y asombro en el lector.

5. La literatura debe abarcar la lengua en su más elevada dimensión.

Estos son los principios rectores de su obra que podríamos aplicarlos específicamente al caso que nos ocupa, la primera obra narrativa de Borges, Historia universal de la infamia, sobre la que pretendemos un acercamiento estético, literario, ético y filosófico.

La conformación del escritor Borges no tendría, sin embargo, mucho sentido sin una serie de principios teóricos sobre los que sustenta su quehacer que delimitan su versatilidad y ofrecen la explicación de uno de los escritores mundiales más geniales de la pasada centuria, sólo comparable a Cervantes, Quevedo o Lope de Vega como autores clásicos y, clásico, lo es ya. 
¿Cuáles son esas señales o principios que delimitan su territorio particular? Creo que la dependencia de Cervantes es fundamental en el terreno estrictamente estructural pero también en la dimensión del hecho creador, en sus juegos literarios, en sus ocultaciones, en sus despechos y alianzas entre lo ensayístico y literario... Borges no existiría sin Cervantes en cuanto concepto teórico y libresco, pero tampoco sin la aportación lingüística de Quevedo, al que consideraba en su libro Otras inquisiciones (1952) como el «primer artífice de las letras hispánicas». De este modo, sólo así podemos colegir que Borges se hace Quevedo en Historia universal de la infamia (1935). Su lenguaje despierta un inusitado interés literario porque procede directamente del conceptismo en su aplicación y desmenuza el lenguaje para obtener de él toda la resistencia verbal al tiempo y al clasicismo estético. Quevedo está presente en estas historias a través de la formación lingüística que las soporta y en la voluntad de estilo, lo único que sostiene al final a un escritor.

Pero es obvio que Borges no es sólo Quevedo y Cervantes. Su proximidad a la literatura de aventuras inglesa de los siglos XVIII y XIX no tendría ningún sentido desdeñarla porque de hecho sostiene el esquema general de estas historias de malvados que comentamos. Hubo en su espíritu de hombre pasivo y de salón, de espadachín de cera, de cuarto de estar y de pirata de tierra adentro, mucho de aventurero en ciernes que, no siendo capaz de llevar a cabo sus aventuras en la realidad, las llevó a cabo con sus palabras, construyendo libros y organizando el mundo libresco. Esta dimensión aventurera de Borges, que está perfectamente señalada en su obra en general, no se debe obviar en Historia universal de la infamia: todo un canto a la acción y a la sed de peripecias y riesgos.

Pero hay más, Borges conoció en Europa la sed de vanguardias, él mismo fue un vanguardista y un acérrimo seguidor del ultraísmo, un profundo conocedor del modernismo y sus técnicas... Todo ello aporta a su literatura la trascendencia de la dimensión lingüística y su capacidad para explorar los límites de la palabra, de la que es un maestro consumado aun en su aparente concisión. 
Y, por último, no podemos olvidar los débitos de Borges a las grandes literaturas orientales que llegan desde China, Japón, India u Oriente Próximo, a la literatura inglesa y a la literatura griega y romana, fundamentalmente de Homero, al que considera uno de sus inmediatos referentes (incluso hasta en la ceguera).

En estas claves consideramos que tiene cabida la literatura profunda, aventurera, creadora y transformadora de la realidad que nos presenta Borges con Historia universal de la infamia, que lejos de ser un libro de juventud, lleno de apariencias y juegos, es una gran obra madura de un hombre que ya es un clásico de la literatura española. Valgan estos versos publicados por Borges en 1981 para dar fin a este prólogo:

\author{
La lenta mano de Virgilio acaricia \\ la seda que trajeron \\ del reino del Emperador Amarillo \\ las caravanas y las naves.
}

Con motivo de su fallecimiento, Edward A. Gargan (1986) resumía en el New York Times su obra con estas palabras:

His writings explored the crannies of the human psyche, the fantastic within the apparently mundane, imaginary bestiaries and fables of obscure libraries and arcane scholarship.

Del que ya Updike había dicho lo siguiente en 1975:

His fables are griten from a height of intelligence less rare in philosophy and physics than in fiction (...) Furthermore, he is, at least for anyone whose taste runs to puzzles or pure speculation, delightfully entertaining.

\title{
2. Aproximación a la infamia y su origen. La función del escritor.
}

Los escritores están condenados a vivir la vida de otros. Transformar la pasividad de escritorio en procesos, acciones y sensaciones que cautiven al lector, pero que, antes, los cautiven a ellos. Un escritor es un asesino si crea la historia de un asesino, y es un anacoreta si cree en él mismo como múltiple y anacoreta. Pero la historia de la literatura está organizada y cautivada por los perdedores, perdularios, 
fracasados, calaveras e infames. Y para ellos la ofensa, la ignominia, la degradación y la abyección es un arte. Habría que consentir en que el escritor, como malversador de los fondos imaginarios, está más cerca de Lucifer que de Dios -aunque lo fuere al crear- y que, a la hora de inventar historias, la imperfección, la caída, el yerro o el pecado es mejor ocasión que la virtud, la probidad o la dignidad. Los extremos de la existencia han sucumbido al encanto de los lectores; en menor medida los personajes anodinos, similares a nosotros mismos. El malo de la película no es sólo la otra cara de la moneda, sino el paradigma de la existencia del texto narrativo.

Sin embargo, aunque no existe necesidad de ello porque Borges no está mediatizado ni limitado por circunstancias algunas como no sea su absoluta libertad de creación y su libérrima voluntad de ironía y sarcasmo creativo, divertimento existencial (podríamos decir) en una línea cercana a Cervantes, ha habido ensayistas que han querido ver en esta exaltación de lo infame un acercamiento a la realidad de su país, como nos decía Guillermo Tedio²:

Es interesante observar que Borges titule el libro en el que incluye HER, Historia universal de la infamia, volumen publicado, como ya anotamos, en 1935, uno de los años que conforman en Argentina la llamada 'Década infame' (avance del fascismo europeo, imposiciones comerciales desventajosas de Gran Bretaña a la economía gaucha, recesión, gobierno militar, fraudes electorales), lo que parece ser, a pesar del proverbial alejamiento de Borges de la temática política, un guiño tropológico malicioso a la historia de su país.

Mucho de recreación y divertimento, no obstante, puede encontrar el lector en ellos, como el propio Borges observó desde la distancia de la tercera persona pero hablando de su propia obra:

Los doctores del Gran Vehículo enseñan que lo esencial del universo es la vacuidad. Tienen plena razón en lo referente a esa mínima parte del universo que este libro. Patíbulos y piratas lo pueblan y la palabra infamia aturde en el título, pero bajo los tumultos no hay nada. No es otra cosa que apariencia, que una superficie de imágenes, por eso mismo puede acaso agradar.

${ }^{2}$ Véase Tedio en la referencia bibliográfica final. 
El hombre que lo ejecutó era asaz desdichado, pero se entretuvo escribiéndolo; ojalá algún reflejo de aquel placer alcance a los lectores ${ }^{3}$.

Pero en última instancia estos escritos de Borges deben ser vistos como una síntesis entre los alimentos del gran lector que siempre fue, los rudimentos de la erudición, el proceso de simbiosis entre géneros (que algunos en el momento actual lo dan como una novedad, ¡qué ironía!) y la capacidad de seducción del lenguaje como hecho creador máximo: "La erudición alimenta una construcción que, aunque apoyada en datos fidedignos, los distorsiona y en los intersticios de la distorsión se fundamenta la invención" ${ }^{4}$.

En cualquier caso, el concepto de infamia no debe ser apreciado, en absoluto, como una idea moral, como se ha dicho:

Historia universal de la infamia (1935) contiene una atractiva galería de malhechores, pero Borges no considera básicamente a la infamia como un tema moral; sus cuentos no sugieren de ninguna manera un cuestionamiento de la sociedad, de la naturaleza humana o del destino. Tampoco sugieren el punto de vista despreocupado de Lafcadio, el héroe nietzscheano de Gide. Aquí, en cambio, la infamia funciona como un principio formal, estético. Las historias, literalmente, no tendrían forma si no fuera por la presencia, en su núcleo mismo, de la villanía. Los mundos que se invocan son muchos y diferentes: plantaciones de algodón cerca del Mississippi, mares australes infestados de piratas, el viejo oeste, los barrios bajos de Nueva York, cortes japonesas, desiertos árabes, etcétera. Todos estos mundos no tendrían forma sin la presencia ordenadora de un villano en su centro ${ }^{5}$.

\section{Pero también y quizá pudiera suceder que}

el tema borgiano de la infamia podría ser simplemente otra forma del esteticismo de fin de siécle, un último estertor de la agonía romántica. $\mathrm{O}$, tal vez peor, Borges podría estar escribiendo por desencanto moral como un escape a las trampas del estilo ${ }^{6}$.

\footnotetext{
${ }^{3}$ Borges (1980: 150).

${ }^{4}$ En Bibliografía viene la referencia completa de Glantz.

${ }^{5}$ Quesada, R. (1999).

${ }^{6}$ Ibidem. "Probablemente porque Borges es un escritor tan brillante, su mundo especular es también, aunque siempre de manera irónica, profundamente siniestro. Los matices del terror van desde el
} 
Borges en Historia universal de la infamia (1935) quiso atraernos hacia el envilecimiento y sus conquistas de la mano de personajes históricos o legendarios: Lazarus Morell, Tom Castro, la viuda Ching, Monk Eastman, Bill Harrigan, Kotsuke no Suke, Hakim de Merv, Francisco Real... Piratas, delincuentes, asesinos... son los personajes de la fábula, los histriones de este espectáculo literario que es la vida. Personajes que viven en el infierno. Infierno al que dedicó su escrito “La duración del infierno" perteneciente a su libro Discusión (1932) ${ }^{7}$. Tras advertirnos que su creación no es privativa de la iglesia católica y generar una serie de teorías históricas sobre el porqué de su esencia, afirma, como es el caso de estos asesinos que pueblan su infamia, que se trata de individuos que "sucumben a la fantasmidad de su ser, pero se renuevan entre la descendencia diabólica" $\mathrm{y}$, tras advertir del poder y la suculencia de este infierno tanto en cuanto de sus protagonistas, concluye que "en el impensable destino nuestro, en que rigen infamias como el dolor carnal, toda estrafalaria cosa es posible, hasta la perpetuidad de un Infierno, pero también que es una irreligiosidad creer en él". En consecuencia, infierno como arte literaria y proceso creador.

Según el DRAE la infamia en una primera acepción es el descrédito, la deshonra, y, en una segunda acepción, maldad, vileza en cualquier línea. La infamia es una degradación del ser humano que se comporta siguiendo sus más bajos instintos y perfecciona lo que se ha dado en llamar el infierno, también el infierno de Borges.

Pero en esos componentes infames incluso hay que advertir la voluntad de estilo, el valor simbólico-alegórico de todo el proceso, la correspondencia entre el hecho literario, el hecho festivo y su mundo imaginario. Barros-Lémez ${ }^{8}$ relataba de este modo las diversas infamias a las que asistimos:

gusto criminal de la Historia universal de la infamia hasta el mundo más obscuro y desaliñado de Ficciones".

${ }^{7}$ Borges (1980: 84-85).

8 Véase la referencia completa de Barro-Lémez en Bibliografía. 
En Morell tenemos la infamia del Padre las Casas, la de los blancos esclavistas, la de los 'poor whites' y la de los mulatos. Por contraposición, la infamia redimible de los esclavos. En Castro, la 'infamia' es tanto la maquinación de Ebenezer Bogle como la de los parientes de Lady Tichborne (...) En la viuda Ching, las infamias van desde los accionistas del negocio de la piratería, pasando por la relación entre el poder imperial y sus súbditos, hasta llegar a la recuperación de la zorra por el dragón. Para el relato de Eastman, las infamias van desde la propia New York y sus códigos vitales -enfrentados a los de Buenos Aires- pasando por todo la saga de Eastman en esa ciudad y posteriormente en la infamia de la guerra europea, que amplía la del personaje. Para Bill Harrigan, la infamia se centra en su desprecio por la vida ajena, la insensibilidad y la falta de sentido de su accionar, así como del medio en que se mueve, hasta su muerte que lo convierte en atracción pública 'infamante'. En la historia del incivil maestro de ceremonias, el enfrentamiento entre la infamia real -la de Kotsuké no Suké- y la irreal -la del consejero Kuranosuké- da los parámetros para otros niveles de infamia, ligados a tradiciones absurdas e inhumanas o, en otro sentido, así vistas desde nuestra perspectiva actual. Finalmente, en Hákim de Merv, la infamia central de su herejía está rodeada de las infamias de la persecución religiosa, las de enfermedades e ignorancias, las de transmutación de la realidad -la labor de tintorería, de cambio de colores- para finalizar en la de la traición recibida.

Pero existe otra percepción de la infamia que radica en la relación que existe entre el estilo y el concepto en sí. De modo que se pueden establecer puntos de contacto entre uno y otro, habida cuenta de la permanente relación entre literatura y proceso creador, entre el texto y el intertexto y sus similitudes y diferencias en aras de dotar a éste de una nueva visión. Al respecto decía Alfonso del Toro ${ }^{9}$ lo siguiente:

Borges forma su literatura basándose en procedimientos desterritorializantes tales como 'falsear', 'tergiversar', 'intercalar' donde el contenido orillero ('patíbulos', 'piratas', 'infamia') no juega un papel principal, sino su transportación, transmutación llevándolo a un nivel puramente literario o autorreferencial ('pero bajo los tumultos no hay nada'), donde reina el placer estético ('irresponsable juego' / 'el hombre que se entretuvo'). La 'infamia' es la osadía del plagio, pero de un plagio especial, que ostenta y escenifica el préstamo, es un plagio descentrante, desplazante, esto es, tergiversador, subvertidor, recodificador y transmutador de los textos leídos. La 'infamia' es la creación de textos originales a espaldas de otros originales formando así una cadena infinita de textos, una red dialogizante.

\footnotetext{
9 Toro (2006: 115).
} 
Y él actuó también como una especie de traductor, tergiversador, relector, escritor que dirime su creación desde lo ya creado para volver a crear ahora algo diferente. Algo similar al proceso creado por Cervantes ${ }^{10}$, al menos inicialmente en el punto de vista adoptado: Cervantes se vale de los personajes que pueblan los libros de caballerías para crear un modelo que ya es el de Cervantes; Borges se basa en los modelos de malhechores para crear sus propios modelos, que ya son definitivamente

10 Toro (1993). El ensayista afirma que "su trabajo describe cómo estos autores tratan de leer y de interpretar el mundo y los signos, y precisamente éste es el lugar de la similitud epistemológica o el eje sémico en común de Cervantes y Borges: ambos autores emprenden un viaje en busca de signos. Don Quijote/Cervantes busca los signos perdidos que lo llenan de nostalgia y de donde surgirán los signos de la Época Moderna; los personajes de Borges persiguen la perlaboración ('Verwindung') de antiguos y preñados signos y la recodificación de nuevos signos, donde la nostalgia de un refugio, de una revelación parecen determinar la escritura de Borges: mas de allí surgirán signos rizomáticos y con ello la postmodernidad. Ambos autores emprenden el camino, abandonan la patria conocida para arrojarse a lo nuevo, a lo incierto: Don Quijote emprende la tarea de restituir el mundo del mito, de los caballeros armados, de los escudos de armas, de los símbolos y de las unidades y analogías que contienen al mundo entero encauzando su trayectoria en un viaje de aventuras determinado por la mimesis. Ese viaje es el motivo del autor implícito para declarar como superado el antiguo mundo, la antigua organización de los signos, la transformación de las analogías en similitudes y diferencias. Borges no tiene como objetivo la restauración de un mundo y signos caducos, sino su perlaboración ('Verwindung'). Por esto su "viaje de aventuras" no es mimético, referencial con respecto al mundo, sino una búsqueda semiótica, los signos hablan constantemente de sí mismos y no se concretizan en significados, sino en significantes. Preguntémonos nuevamente: ¿por qué se ocupan Foucault y Borges de Cervantes? (...) Es evidente que a Borges, en su lectura de Cervantes, le interesa el problema de la mimesis y con ello la relación realidad/ficción, mas en primera línea vale su atención a la relación literatura/literatura. Expresado de otra forma: se trata de la relación entre la escritura/lengua del yo y aquélla del mundo, de la forma en que el mundo se lee y de su interpretación literaria. En este punto se producen las diferencias entre los sistemas sígnicos: mientras Don Quijote se lanza al mundo exterior/real en busca de signos que le permitan confirmar sus lecturas y su mundo libresco, Borges se retrae del mundo exterior/real y se dirige al mundo del pensamiento puro y de los signos puros". 
'copyright' de Borges. Actúa librescamente. Al comienzo más como lector ${ }^{11}$ que como escritor, aunque a resultas conforme su propio mundo:

El universo de Borges se define como una literatura que tiene a la literatura como principal asunto, como su eje central. Como el mismo Borges declara, toda su experiencia es una experiencia leída, no vivida, extraída de las páginas de los libros. Su carácter de lector empedernido era el que le llevaba a afirmar que se enorgullecía más de las páginas leídas que de las escritas ${ }^{12}$.

Borges fue un gran imitador, y como Cervantes creó arte desde la mimesis, recreó e inventó su obra; Borges desde sus expectativas vanguardistas y su formación clásica prorrumpe con un modelo estético similar que será básico en la historia de la literatura desde el Barroco: la deformación, la caricatura, la apariencia creadora, la mimesis creativa:

El diseño en Borges, al igual que el género, se apoya en un contrapunto de referencias y citas que estructuran el relato. Algunas de ellas de difícil o imposible comprobación; otras, decididamente apócrifas y dispersas casi siempre en páginas plagadas de precisiones verificables. La simple lectura nos plantea la dificultad de decidir dónde Borges se atiene a la verdad y dónde la falsea ${ }^{13}$.

Esta visión literaria que no se puede verificar porque existe una voluntad clara de expropiar los límites entre ambas realidades múltiples instituye lo que la ensayista L. Annick14 llama 'narrador-scriptor', la creación de nuevas situaciones y

\footnotetext{
${ }^{11}$ Cordua. Afirma el autor que "la vida de Jorge Luis Borges, se podría decir exagerando un poco, fue un constante ejercicio lingüístico. Una vida, principalmente, de lector, de escritor y de conversador. De sí mismo él afirma que ha hecho 'una vida menos consagrada a vivir que a leer.' Por eso, tanto la persona como su obra se caracterizan por haberle exigido al lenguaje una gran variedad de funciones: en efecto, Borges convierte al castellano en bueno para la poesía, la narración, el ensayo, la conferencia, la entrevista, la crítica y la teoría literaria, la especulación parafilosófica. Además, instaló en nuestra lengua obras de otros idiomas en versiones tan sueltas y legibles que casi pueden pasar por originales".

12 Ruiz Pérez (1986: 113).

${ }^{13}$ La referencia completa de Rey se halla en Bibliografía.

${ }^{14}$ Annick (1997).
} 
estipulaciones para la creación literaria, en las que el narrador bascula entre la ficción y el discurso anterior, probablemente histórico o no, quizá legendario. Existiría en palabras suyas un transcriptor de una fuente histórica (pero es una fuente no aclarada, no mostrada) lo que produce dudas en torno a su autenticidad, convirtiéndose así el escritor en una especie de mediador.

$Y$, en consecuencia, la infamia no posee un valor moral sino literario. El alimento que lo sustenta es la recreación novelesca. No interesa tanto la historia en sí, que es conocida por muchos, sino el proceso creativo de la misma, el proceso de 'literaturización' de la misma, su componente estético. Obviamente existen los dos grandes principios sobre los que se sustenta su literatura, el entretenimiento y la conmoción diversa ante el hecho literario, pero, sobre todo, y fundamentalmente, el hecho en sí de la creación literaria con todos los procesos artísticos que ésta conlleva. Y observamos que Borges es organizado, contenido, remiso a la expansión literaria y sumiso al original, ofreciendo pocas novedades y sí bastante fidelidad al modelo inicial tomado librescamente. Pero como escritor avezado emplea los recursos que eran consecuentes en el barroco y en Cervantes: la ironía, el desdoblamiento de los procesos significativos, las recreaciones, las deformaciones, las aportaciones novedosas, las ambigüedades, el retorcimiento del proceso creador hasta fundar un nuevo elixir literario. Como nos recuerda Alberto Giordiano ${ }^{15}$ al hablar sobre el libro de Annick

una de las hipótesis más fuertes de Jorge Luis Borges: œuvre et manœuvres, formulada y argumentada en el capítulo 'D'un support coupable à un autre', se refiere específicamente a la composición de Historia universal de la infamia. Sobre la base de que toda recopilación entraña un trabajo de creación, después de reconstruir el contexto de revistas y editoriales en las que Borges había publicado y publicaba en la década del 30, la autora se ocupa de demostrar cómo los elementos formales de Historia manifiestan, indirectamente, las mismas concepciones literarias que se afirman en los relatos recopilados.

\footnotetext{
${ }^{15}$ Referencia completa de Giordano en Bibliografía.
} 


\section{Disquisiciones en torno a los «ejercicios de prosa narrativa». Intertextualidades.}

Los primeros trabajos narrativos de esta obra de Borges, reunidos en 1935 en Historia universal de la infamia, fueron escritos entre 1933 y 1934, y fueron publicados inicialmente en la revista Crítica ${ }^{16}$, en su suplemento sabático denominado Revista Multicolor de los Sábados ${ }^{17}$, que dirigió Borges junto a Ulises Petit de Murat, entre agosto del 33 y septiembre del 34, una revista que ha sido tildada como sensacionalista, dinámica, inquieta, sensiblera, demagógica e informada, y donde comenzó la serie de relatos aventureros, fantasiosos, escritos a partir de fuentes enciclopédicas que luego reunió en su primera incursión por la prosa narrativa en Historia universal de la infamia. Él los consideraba en el "Prólogo a la primera edición", escrito en Buenos Aires el 27 de mayo de 1935, «ejercicios de prosa narrativa». Así lo recordaba Aguinis, ${ }^{18}$ para el que todavía no firmaba con su nombre sino con el seudónimo de H. Bustos:

Aún no se atrevía a redactar ficción pura y, sin embargo, esos relatos anticipaban la mayoría de sus rasgos distintivos. El volumen se llama Historia Universal de la Infamia. Ocupa un ambiguo espacio entre la ficción y la no ficción, habitado por delincuentes históricos que actuaron en los contornos de la sociedad. Alternan extremistas puritanos con inventores de mundos falsos que alienaban a sus corifeos. Borges se burla de estos villanos y de su repugnante conducta. Los convierte en personajes, aunque reduzca su vida 'a dos o tres escenas', como advierte en el prólogo.

En consecuencia, el valor que les daba era relativo, al menos desde esa supuesta modestia (que sonaba más a afectación) que proyectaba. Se trataba de relecturas (para Borges lo fundamental fue siempre el placer de la relectura) de

\footnotetext{
16 Crítica (Buenos Aires) Suplementos "Revista Multicolor de los Sábados" (1933 - 1934)

17 Había colaboraciones de Swift, Kipling, Chesterton, Wells..., así como comentarios bibliográficos, reseñas, etc., y colaboraciones de escritores argentinos. Existe mucho de sensacionalismo en el suplemento y también curiosidades de diverso tipo, relatos terribles de personas condenadas a morir, ilustraciones, etc.

${ }^{18}$ Aguinis (2006).
} 
Stevenson, Chesterton ${ }^{19}$ y los primeros filmes de Von Sternberg ${ }^{20}$ con las aportaciones de la biografía de Evaristo Carriego ${ }^{21}$, un poeta olvidado que él rescató

19 Borges (1962: 205-208). En estas páginas Borges no es ajeno a los elogios que propala sobre Chesterton del que se siente heredero y en el que destaca grandes aciertos que luego heredarían otros como Kafka. Dice entre otras cosas sobre él: "La maestría no agota la virtud de estas breves ficciones; en ellas creo percibir una cifra de la historia de Chesterton, un símbolo o espejo de Chesterton. La repetición de su esquema a través de los años y de los libros (...) parece confirmar que se trata de una forma esencial, no de un artificio retórico (...) Chesterton se defendió de ser Edgar Allan Poe o Franz Kafka, pero que algo en el barro de su yo propendía a la pesadilla, algo secreto, y ciego y central. No en vano dedicó sus primeras obras a la justificación de dos grandes artífices góticos, Browing y Dickens: no en vano repitió que el mejor libro salido de Alemania era el de los cuentos de Grimm. Denigró a Visen y defendicó (acaso indefendiblemente) a Rostand, pero los Trolls y el Fundidor de Peer Gynt eran de la madera de sus sueños, The stuff his dreams were made of. Esa discordia, esa precaria sujeción de una voluntad demoníaca, definen la naturaleza de Chesterton".

${ }^{20}$ Servelli (2002-2003: 88). Dice: "La ley del hampa (Underworld, 1927) uno de los films de Sternberg asiduamente citado por Borges con notas de admiración, nos proporciona un caso de aplicación precisa de este procedimiento, que Borges define como "pormenores lacónicos de larga proyección", esto es, momentos privilegiados de una narración que disponen una concatenación de motivos donde las justificaciones verosímiles ceden su función a un ordenamiento mágico, "donde profetizan los pormenores". En una de las escenas iniciales del film, correspondiente a la presentación de la protagonista femenina, Feathers (Plumas) - caracterizada por Evelyn Brent - , la cámara sigue en su recorrido el ingrávido vuelo de una pluma, cuyo camino aéreo nos lleva directamente al personaje evocado; hacia el final de la película, el gangster Bull Weed (George Brancroft) conocerá al salir de la cárcel, por una de esas plumas halladas en su guarida, que su amante lo ha engañado con su abogado".

${ }^{21}$ Poeta argentino nacido en Paraná, Entre Ríos, en 1833. Se educó en Buenos Aires, y desde joven participó en tertulias literarias y movimientos de tipo intelectual. Escribió en diversas publicaciones de la época, como «La Protesta», «Ideas», «Caras y caretas» y otras. Su obra literaria se extendió al teatro y al cuento dejando varias publicaciones junto a su único libro de versos editado en vida, Misas herejes, en 1908. Después de su muerte, ocurrida en 1912, se publicó el conjunto de su producción poética con el título de Poemas póstumos y La canción del barrio. J. L. Borges escribió sobre Carriego un ensayo en 1930 que lleva por título Evaristo Carriego. Era amigo del padre de Borges a quien visitaba habitualmente los domingos de vuelta de las carreras. Puede ser que Borges, cuando niño observara aquellos diálogos de su padre con Carriego y recogiera en su mente el tartamudeo revelador, un conjunto de detalles que atestiguan los testimonios escritos de críticos como Marcelo del Mazo, 
de la indiferencia desde que lo conociera de pequeño, junto a su padre, en su casa familiar durante muchos domingos. Este autor le permitía a Alfonso del Toro 22 decir algunas de las claves de la escritura de Borges:

El eclecticismo es total y la escritura es el resultado de una lectura de diversos autores de cine y lo más sensacional de una biografía inventada por Borges mismo, Evaristo Carriego, un texto sobre un poeta popular 'amigo y vecino', 'casi invisible' (Autobiografía 84-85) cuya referencia real comienza a desaparecer detrás del proceso de la escritura: “Cuanto más escribía, menos [le] importaba [su] héroe". Parte de un lugar de la periferia de Buenos Aires, de los "tristes arrabales", de un autor que muere a los veintinueve años y deja una sola obra. Durante el proceso de escritura la persona de Carriego desaparece cediendo el espacio a la metrópolis de Buenos Aires.

En la misma idea anterior de «ejercicios», aplicados a los escritos narrativos de Historia universal de la infamia, insistirá casi veinte años más tarde en el prólogo a una edición de 1954: “Son el irresponsable juego de un tímido que no se animó a escribir cuentos y que se distrajo en falsear y tergiversar (sin justificación estética alguna vez) ajenas historias". Palabras que le merecen a Midence ${ }^{23}$ el siguiente comentario:

Esas ajenas historias no son más que las propias, las historias que él siempre quiso protagonizar y que, en algunas ocasiones protagonizó como cuando hablaba de individuos librescos, pasivos, indefensos, impostores, cosmovisionarios pero, de igual manera cuando hablaba de criaturas cuchillescas o aventuras con un cuerpo constitutivo de intriga, de búsqueda o quizá fantástico que tanta fama le ha granjeado ya sea, el protagonista Dhalman o el detective Lonnrot o el heresiarca de Tlon Uqbar Orbis tertius no son otra cosa que los personajes simbolizando al mismo Borges. Pues el símbolo lo que hace es ocultar y representar connotativamente a otro objeto.

Roberto F. Giusti o José Gabriel. En su ensayo sobre Carriego, Borges lo que buscaba era rescatar para el placer de lectores exigentes un poeta menor que la crítica argentina había creído insignificante, digno apenas del aplauso de consumidores de letras de tango y semanarios sentimentales. En aquellos años, Borges tiene unos treinta y admira polémicamente a Carriego, que le ha llegado por vivo contacto familiar. El joven Borges ataca a los que niegan a Carriego porque no es bastante culto (el poeta culto era, entonces, Leopoldo Lugones). Y quiere rescatar su poesía, la de un Buenos Aires de compadritos y conventillos, de tango y duelos a cuchillo.

22 Toro (2006: 113-114).

${ }^{23}$ Referencia bibliográfica de Midence en Bibliografía. 
Estas historias iniciales de Borges fueron celebradas con reseñas elogiosas por Amado Alonso en la revista Sur celebrando la llegada de una nueva voz narrativa, sin embargo, pronto pasarían desapercibidas y olvidadas, no siendo hasta el año 1954 cuando, en la estela de Ficciones y El Aleph, comenzarían a ser tenidas en cuenta ${ }^{24}$. Pero, en última instancia, lo que sí se observa en ellas es un fenómeno que cultivará durante mucho tiempo y es la clave de su escritura: la alianza entre la literatura anterior y la suya propia, la trascendencia del intertexto y el subtexto en toda su producción, este juego de coaliciones que a su vez genera otros textos diferentes partiendo de la idea de que la realidad presenta una singladura caótica y la literatura ha de crear un orden determinado:

De ahí la constante vuelta a los mismos temas, la fijación en un delimitado número de ideas, que Borges fatiga volviendo constantemente sobre ellas, hasta crear con esta repetición un ritmo cíclico, que constituye en representación universal ${ }^{25}$.

Es sintomático de su producción y es algo que ya llegaba desde el siglo XVI: el propio Cervantes, al que tanto admiraba Borges ${ }^{26}$, lo aplicó con frecuencia, así como otras técnicas en las que entraremos en su momento. Margo Glantz ${ }^{27}$ afirma que

\footnotetext{
${ }^{24}$ Costa (2005). Dice Costa que "desde entonces han sido mitificadas por los borgianos, que las han considerado el campo de experimentación de las técnicas narrativas, el punto de referencia para valorar sus < progresos> como narrador y también para comparar las fuentes con las versiones que Borges nos ofrece, e incluso, para maravillarse de aquellas historias totalmente inventadas por él como si la invención fuera un hecho insólito en la historia de la literatura. Borges contribuyó a esta mitificación empleando en sus prólogos y entrevistas que se trataba únicamente de meros <ejercicios> de un joven tímido, que no se atrevía a escribir un cuento directo. Fue sólo en 1970, después de traducir esos textos al inglés con Norman Thomas de Giovanni, cuando Borges admitió que eran $<$ hoaxes $>$, supercherías, o sea, obras de invención, de creación".

${ }^{25}$ Ruiz Pérez (1986: 116).

26 Spielmann (2005: 242). Afirma la escritora: “De Mojica sigue a Williamson para diferenciar tres etapas de 'la evolución del interés permanente de Borges por el Quijote y las concepciones que se hace de esta novela' En la primera, en la etapa vanguardista y luego nacionalista de Borges, Cervantes es el 'modelo de autor/héroe/dios'. Hacia 1924 la ambición de Borges es hacer para Buenos Aires lo que había conseguido en 1922 Joyce con Dublín: 'fundar un omphalos', el ombligo griego (antiguo) del mundo, en un poema épico o en una novela capaces de crear, como Ulysses, una mitología, de
} 
Borges ejercita su vacilante pluma en un texto flagrantemente intertextual. Es más, si su producción ya largamente extendida por el siglo se coloca en dos extremos y si se revisa el tipo de libros que escribió cuando empezaba y ahora que termina, constatamos dos libros, uno del principio de su carrera, Historia universal de la infamia, fechado en 1935, y Libro de sueños, aparecido en 1976, por tanto del final. Ambos son presentados en sus prólogos como "ambiguos ejercicios" sobre los cuales no se tiene mayor derecho que el que podría tener un traductor o un lector. Es decir, su actividad escrituraria es concebida como un ejercicio que permite luego pasar a una "trabajosa composición" de ficciones. Ficción e intertextualidad, pues. Borges escribe ficciones que se inscriben en el universal ámbito de lo intertextual y su filiación es ampliamente declarada y su participación como escritor denigrada y soslayada.

Sean ejercicios, contaminaciones literarias, absorciones, juegos 28 , recreos, intertextualidades, solaces o travesuras -que en la obra de Borges todo forma parte del mismo proceso creador- en la que está presente un espíritu barroco preciso en el deambular por escritos anteriores y ofrecer una nueva visión, una nueva imagen, una nueva caricatura:

¿Cuál es el sentido entonces de la intertextualidad en Borges? Las citas de autores, las breves referencias a teorías distintas y hasta opuestas versan sobre interpretaciones o postulaciones de la realidad. Esta multiplicidad pone de manifiesto que el mundo admite infinitas

constituirse en el (moderno) clásico argentino para construir la nación. Este propósito toma hacia 1930 los rasgos del proyecto de una narración en prosa o una novela, 'lo que suscita una reflexión sobre la realidad'. El ejemplo de Cervantes pasa así a enseñarle a Borges 'lo decisivo: la 'magia' de contar un relato'. 1939 marca la fecha clave de la segunda etapa, cuando Borges tiene que abandonar por irrealizable para él el proyecto de novela que no ha conseguido escribir -Norah Lange lo rechaza definitivamente después de una relación de diez años-, debe reescribir la novela de su padre y emplearse en la biblioteca Miguel Cané. 'Pierre Menard, autor del Quijote', 'nota necrológica con fecha, indicación de lugar, pero sin firma', señala entonces el cambio hacia 'una concepción más modesta del autor como lector'",.

27 Véase la referencia bibliográfica completa de Glantz en Bibliografía.

${ }^{28}$ A este respecto decía Ramírez (1990) lo siguiente: “Me maravillaba ver cómo Borges articulaba sus distintos instrumentos, o ámbitos de la ficción, como un todo, la filosofía, la teología, la mitología, y la crítica, literaria, las traducciones, las citas de autores verdaderos, o imaginados. Nada escapa a esta inmensa urdimbre, desde la que siempre estará haciéndonos un guiño, porque al fin y al cabo Borges viene a resultar un formidable humorista. Un humorista con vestiduras de escritor serio, como Chesterton, o como Quevedo". 
interpretaciones y ninguna. La intertextualidad parece remitir siempre a la impotencia del conocimiento y a la nada que el mundo puede llegar a ser para quien advierta esa impotencia ${ }^{29}$,

pero también la voluntad de hermetismo que no significa ocultación sino la voluntad fabuladora de la interpretación. Como Cervantes, Borges no dice nunca la última palabra ni la puede decir nunca ningún crítico sobre él porque siempre existirá la riqueza de la multiplicidad de puntos de vista y de guías, quizá todas válidas y contradictorias, para interpretar su obra literaria.

\section{Por eso dirá Borges:}

Ya el excesivo título de estas páginas proclama su naturaleza barroca. Atenuarlas hubiera equivalido a destruirlas; por eso prefiero, esta vez, invocar la sentencia quod scripsi, scripsi (Juan, 19, 22) y reimprimirlas, al cabo de veinte años, tal cual ${ }^{30}$.

Barroco que era entendido por el escritor argentino como un estilo que agota sus posibilidades en sí mismo, llegando hasta la caricatura. Y, también, la etapa final de todo arte cuando éste se recrea, avanza en exceso y sus medios los dilapida a través de su exhibición intelectual. Pero, a la vez, mucho de humorismo existe en toda labor intelectual, aunque sea un humorismo involuntario, como le sucede a Baltasar Gracián, o consentido -dice Borges-, como le acaece a John Donne.

La obra está conformada por los siguientes títulos: El atroz redentor Lazarus Morell, El impostor inverosimil Tom Castro, La viuda Ching, pirata, El proveedor de iniquidades Monk Eastman, El asesino desinteresado Bill Harrigan, El incivil maestro de ceremonias Kotsuke No Suke, El tintorero enmascarado Hakim de Merv, Hombre de la esquina rosada, y Etcétera.

El relato inicial, El espantoso redentor Lazarus Morell, se desarrolla en la primera mitad del siglo XIX, si bien es cierto que está presente el s. XVI a través de las referencias existentes a Bartolomé de las Casas; El impostor inverosímil Tom Castro

\footnotetext{
${ }^{29}$ Véase la referencia bibliográfica completa de Rey en Bibliogafía.

${ }^{30}$ Borges (1980: 149).
} 
tiene lugar a finales del siglo XIX; La viuda Ching, pirata a finales del XVIII; El proveedor de iniquidades Monk Eastman, también en el siglo XIX como El espantoso redentor Lazarus Morell, pero entre finales y las primeras décadas del XX, como Hombre de la esquina rosada; El asesino desinteresado Bill Harrigan también en el XIX, pero en la segunda mitad; El incivil maestro de ceremonias Kotsuké no Suké", a principios del XVIII; y El tintorero enmascarado Hákim de Mero podríamos situarlo a mediados del siglo I. Desde el punto de vista espacial, los relatos se sitúan en los siguientes lugares: dos en China y Japón, tres de ellos en EE.UU., uno en Inglaterra, otro en América del Sur y en el Medio Oriente.

Se trata de historias verosímiles o a las que dota de una verosimilitud necesaria, como a todos sus textos, que estarían a caballo entre el cientifismo y la ficción, entre la realidad y la fantasía, entre el texto y el intertexto, sin saber muchas veces hacia dónde se encuentra o desde dónde podemos advertir sus límites. Por eso estos relatos no debemos entenderlos como pertenecientes a la realidad. De hecho sería absurdo plantearnos en Borges este asunto. Afirmaba en este sentido Eloy Martínez ${ }^{31}$ que

la declaración de Borges sobre la falsificación de hechos en Historia universal de la infamia acierta con dos de los estímulos mayores de las ficciones verdaderas: llenar un vacío de la realidad, como en el caso de Schwob, escribir lo omitido, plantar la bandera de la imaginación en los sitios por los que no se ha aventurado la historia, o bien rehacer la realidad, rescribirla, transfigurando según las leyes del propio deseo o, como bien señala Borges, del placer.

\section{Y también como señala Rey Beckford ${ }^{32}$,}

la ahistoricidad de estas historias de la infamia no deriva de la presunta falsificación de los hechos. Falsificación, por otra parte, cuyos alcances no pueden ser determinados a través de una simple lectura. Ignoramos dónde Borges se atiene a los hechos y dónde los falsea. Sabemos, en cambio y con absoluta certeza, que la totalidad es ficticia. Y lo sabemos no porque el texto lo declare de un modo expreso, sino porque lo oculta de un modo expreso. Es

\footnotetext{
${ }^{31}$ Martínez (2005).

32 Véase la referencia de Rey Beckford en Bibliografía.
} 
a través de un procedimiento irónico, de un deliberado exceso de semejanzas y similitudes con la historia, que Borges alcanza la ficción.

En estas historias Borges usa del retrato como técnica para derivar hacia lo simbólico-alegórico, pero el relato se sostiene sobre él mismo, sobre la fuerza de su palabra y el poder de contención de su lengua. La eliminación de lo complementario o lo innecesario y la predisposición a un lenguaje de enorme elevación literaria hace considerar a estos relatos como los más interesantes escritos por Borges. Le bastan unos cuantos trazos para erigir una imagen y un personaje, sobre los que crea una especial imantación y atractivo. Por ejemplo, cuando dice de Anne Bonney: "Era una irlandesa resplandeciente, de senos altos y de pelo fogoso, que más de una vez arriesgó su cuerpo en el abordaje de naves". La lengua se puede emplear de muchas formas, pero en incontables ocasiones Borges la emplea del modo más expresivo y certero: la irlandesa podía tener otros adjetivos pero él le aplica el de 'resplandeciente' que para una pirata no deja de llamar la atención. Como también el fijarse en sus senos y aplicarles el calificativo de 'altos' o el pelo 'fogoso', o la forma en que presenta que era una persona valiente. Cualquier otro escritor hubiera dicho era una mujer valerosa, pero él prefiere un rodeo literario: “Más de una vez arriesgó su cuerpo en el abordaje de naves". Es una forma de presentar el recurso lingüístico y Borges descuella no sólo por su creatividad y recreación literaria sino por su conformación de un estilo, un estilo que tiene como norte fundamental la directa comunicación y sus posibilidades. Al respecto decía en su texto "La supersticiosa ética del lector" 33 , recogido en Discusión (1930), lo siguiente:

La condición indigente de nuestras letras, su incapacidad para atraer, han producido una superstición del estilo. Una distraída lectura de atenciones parciales. Los que adolecen de esa superstición entienden por estilo no la eficacia o la ineficacia de una página sino las habilidades aparentes del escritor: sus comparaciones, su acústica, los episodios de su puntuación y de su sintaxis (...) No se fijan en la eficacia del mecanismo, sino en la disposición de sus partes. Subordinan la emoción a la ética, a una etiqueta indiscutida más bien.

\footnotetext{
${ }^{33}$ Borges (1980: 41-42).
} 
Y en otro momento, en torno a la importancia y la precisión que le daba a su estilo, se decía de él lo siguiente:

Borges no dejaba de apuntar, por supuesto, si ustedes recuerdan, que la pasión de Flaubert por limpiar cada párrafo de repeticiones y rimas impertinentes, no era sino una manía de quien lee, pero no un estorbo para quien escucha, porque en fin de cuentas la prosa es oral; y que la mejor manera de escribir un relato de ficción es en verso, para hacer que el lector reconozca, a través del artificio, que se trata de mentiras, como en una penitencia constante. Consejos, por supuesto, que alguien como él, que perseguía la perfección con delirio, muy poco practicó. Y, prueba en su contra, siempre buscó alejar al lector de la idea de que el acto de leer es el acto de aceptar una mentira, tratando de fingir a fondo para lograr algo que fuera lo más parecido a la verdad, aún con trampas, como las citas falsas de autores que nunca existieron ${ }^{34}$.

Los relatos de Historia universal de la infamia poseen a pesar de sus diferencias evidentes unos elementos comunes:

a) Se trata en su mayoría de personas o individuos que forman parte de creaciones ajenas $y$, sin embargo, son conformados con una originalidad manifiesta.

b) Son seres atroces que sólo pueden generar una mezcla de repulsión o atractivo tanto vital como literario.

c) No son personajes completamente definidos y cerrados, sino abiertos y oscuros, alambicados y complejos, con tendencia al travestismo y la metamorfosis. Así lo comenta Álvaro Barros-Lémez ${ }^{35}$ :

Arthur Orton será sucesivamente Tom Castro y Roger Charles Tichborne; Bill Harrigan pasará a ser Billy the Kid; la viuda Ching se trasmutará en Brillo de la Verdadera Instrucción; Edward Osterman será Monk Eastman pero también Edward Delaney, 'alias William Delaney, alias Joseph Marvin, alias Joseph Morris, alias Monk Eastman', con lo cual el propio nombre que será posteriormente dado como verdadero y nacido de la americanización de un apellido originalmente europeo, queda también en cuestión; Hákim de Merv será Al Moqanna, 'el Profeta Velado', el 'Enmascarado', 'El Velado' o utilizará la cabeza de toro como máscara

\footnotetext{
${ }^{34}$ Ramírez (1990).

${ }^{35}$ Véase la referencia bibliográfica de Barros-Lémez en Bibliografía.
} 
visible. Morell y el vengador de Asano Takumi no Kami -el consejero Kuranosuké- se 'enmascaran' a través de sus acciones y su ubicuidad, aunque el primero morirá como Silas Buckiey en el hospital de Natchez.

d) La capacidad para adulterar o desnaturalizar la verdadera razón de ser de los hechos o de los acontecimientos y usar la impostura como añagaza. Por ejemplo, Ebenezer Bogle inventa que Orton se hace pasar por Tichborne: “Intuyó que la enorme ineptitud de la pretensión sería una convincente prueba de que no se trataba de un fraude" 36 .

e) La trascendencia de la muerte o la caída de todos los antihéroes de estos relatos, que acaban siendo efímeros momentos de un sueño. El caso más significativo puede ser el de Billy Harrigan o Billy the Kid:

“El hombre estaba muerto. Le notaron ese aire de cachivache que tienen los difuntos. Lo afeitaron, lo envainaron en ropa hecha y lo exhibieron al espanto y las burlas en la vidriera del mejor almacén" (Borges, 1980: 181).

f) Todas ellas son personas temidas pero también odiadas. Por ejemplo, Kira Kotsuké no Suké, el odiado maestro de ceremonias.

g) La importancia que adquieren una serie de grandes principios como el valor, la justicia, la amistad...

h) La trascendencia de la lectura como instrumento primigenio sin el cual no hubieran sido posibles estos relatos. Borges sobre todo se consideraba un buen lector, como hemos constatado. Y esto se precisa a través de un aire historiográfico que le da a algunos fragmentos de sus relatos que parecen sacados directamente de una disertación de erudición historiográfica:

Si no me equivoco, las fuentes originales de información acerca de Al Moqanna, el Profeta Velado (o más estrictamente, Enmascarado) del Jorasán, se reducen a cuatro: a) Las excertas de la Historia de los jalifas conservadas por Baladhuri, b) el Manual del gigante o Libro de la precisión y la revisión del historiador oficial de los Abbasidas, ibn abi Tai Tarfur, c) el códice árabe titulado La aniquilación de la rosa...

${ }^{36}$ Borges (1980: 161). 
i) La imbricación de una serie de elementos en distintos relatos creando una especie de vasos comunicantes o de malla entre ellos. Barros-Lémez ${ }^{37}$ cita

las menciones a la Biblia en El impostor inverosímil Tom Castro (Salmos 107:23) o en el Prólogo de 1954 (Juan 19:22), referencias y enumeraciones múltiples que se encuentran en varios de los relatos. También, como ocurrirá en relatos posteriores, datos que son creados para un texto y se transpolan a otro, construyendo una red de mutua verosimilitud (tal es el caso de la referencia a la banda neoyorquina de los Swamp Angels, que aparece en El proveedor de iniquidades Monk Eastman y es retomada en El asesino desinteresado Bill Harrigan).

\section{j) La unidad temática de sus personajes y de sus historias que rebelan algo muy pronunciado en su obra, como nos recordaba Sergio Ramírez ${ }^{38}$ :}

Es la identidad de las correspondencias temáticas de su obra, en poesía, en narrativa, en ensayo, una fidelidad apasionada a un número selecto de temas, $u$ obsesiones, que se corresponden ciegamente con su idea del universo, del infinito, del tiempo, de la eternidad, de la realidad, que es siempre ilusoria, del azar, que gobierna los destinos, del ser, que es siempre todos los seres y uno mismo, y de las cosas, "todo es todo. Casa cosa es todas las cosas. El sol es todas las estrellas, y cada estrella es todas las estrellas y el sol" (Historia de la Eternidad). Si nos fijamos bien, todo su intento literario está comenzando siempre de un punto cero, como quien tira sobre el tapete verde los mismos dados, capaces de presentar, en las combinaciones de sus cifras, figuras infinitas.

\footnotetext{
${ }^{37}$ Barros-Lémez afirmaba también la existencia de una serie de temas que aparecen en estos relatos y serán recuperados por el escritor argentino en otras obras: “Quizás el más resaltante sea el que aparece en 'El tintorero enmascarado Hákim de Merv'. Dice el texto: 'la tierra que habitamos es un error, una incompetente parodia. Los espejos y la paternidad son abominables porque la multiplican y afirman'. En Tlön, Uqbar, Orbis Tertius, tenemos dos versiones de la misma idea. La primera es la que el narrador le adjudica a Bioy Casares: 'recordó que uno de los heresiarcas de Uqbar había declarado que los espejos y la paternidad son abominables porque multiplican el número de los hombres'. La segunda es la presunta nota en el tomo XLVI de la Enciclopedia (Anglo-American): 'Para uno de esos gnósticos, el visible universo era una ilusión o (más precisamente) un sofisma. Los espejos y la paternidad son abominables porque lo multiplican y lo divulgan'. Este último, sin duda el más cercano al texto de El tintorero..., y a la idea expresada en la penúltima estrofa de $E l$ Golem. Junto a los arriba mencionados, cabría señalar parentescos entre 'El tintorero...' y elementos que aparecerán en Los teólogos y El Zahir; el tema del número 9 como conformador de mundos -para el primero- y la relación a través de la rosa -para el segundo-: 'el Zahir es la sombra de la rosa y la rasgadura del velo'.

${ }^{38}$ Ramírez (1990).
} 
k) Por otra parte, tal como se deduce del prólogo a la primera edición, estas obras no poseen ninguna intención psicológica sino que más bien pretenden dar una visión externa del personaje en su medio, y todo ello, como afirmaba el profesor de la Universidad de Iowa, Balderston, ${ }^{39}$ se logrará principalmente captando la imaginación visual del lector ("propósito visual") y utilizando

algunas técnicas para causar en el lector un impacto más visual que psicológico, especialmente las enumeraciones heteróclitas (que recurren a elementos de un ambiente determinado que no guardan entre sí otra relación que no sea sintáctica), la ruptura de la continuidad narrativa, y la reducción de una vida a dos o tres escenas emblemáticas. Algunas de esas técnicas -el uso de enumeraciones heteróclitas y el rompimiento de la continuidad narrativa - no deben mucho a Stevenson (el segundo, por ejemplo, proviene evidentemente del montaje cinematográfico rápido, perfeccionado a fines de la década del veinte por Sternberg y Eisenstein), pero la insistencia en una presentación externa, no psicológica, de los personajes, lograda mediante escenas emblemáticas, proviene sin duda de la teoría sobre la novela de aventuras presentada en los diversos textos que hemos comentado.

En este sentido dirá también Servelli ${ }^{40}$ :

La indagación de los procedimientos narrativos del cine por parte de Borges se orienta en la búsqueda de una economía narrativa, a través de una sintaxis menos discursiva que la verbal, es decir, una sintaxis que omita el moroso 'tejido conectivo' (la expresión es de Cozarinsky) propio de la práctica novelística.

1) Un factor común a todas estas historias y a su proceso de construcción es la tendencia de Borges a relacionar siempre las imágenes, situaciones, aspectos, idiosincrasia... hispánica y argentina en relación a los relatos que llegan de otras realidades, a veces sajonas u orientales. Este aspecto esencial lo ve en múltiples detalles Carlos Gamerro ${ }^{41}$ :

En Historia universal de la infamia el procedimiento se realiza de manera sistemática: "El proveedor de iniquidades Monk Eastman" arranca con el fragmento titulado "Los de esta

\footnotetext{
39 Véase la referencia bibliográfica completa de Balderston en Bibliografía.

${ }^{40}$ Servelli (2002-2003: 88).

${ }^{41}$ Véase la referencia bibliográfica completa de Gamerro en Bibliografía.
} 
América" y cuenta el duelo de dos malevos (...) Fiel a este inicio, Monk Eastman es un 'malevo tormentoso' que se pasea con una paloma de plumaje azul en el hombro "igual que un toro con un benteveo en el lomo" y recluta "cien héroes tan insignificantes o espléndidos como los de Troya o Junín." (...) En algún momento de la lectura de esta Historia universal de la infamia comprendemos que Monk Eastman, Bill Harrigan y los samurai que sirven al señor de la Torre de Ako son todos malevos disfrazados, y que la viuda Ching es la mujer cuchillera que la incurablemente machista mitología de los arrabales argentinos no le pudo permitir. Así, esta "historia universal" termina siendo sospechosamente local, y visto desde esta perspectiva (hay otras, claro) "Hombre de la esquina rosada”, lejos de ser el cuento anómalo que rompe la serie, es su natural culminación: todas estas historias de malevos extranjeros le sirven de marco o pedestal al relato fundacional de la mitología orillera.

m) En todos estos relatos el punto de vista adoptado es el de la tercera persona, y en ningún caso la primera, tan habitual en historias posteriores, si hacemos excepción de Hombre de la esquina rosada.

\section{La infame turba de nocturnas aves}

Álvaro Abós (2003) nos refiere cuáles fueron aquellos orígenes borgianos de un modo sintético y dónde se inspiró para escribir esta "infame turba de nocturnas aves" que constituyen los relatos de Historia universal de la infamia ${ }^{42}$, y también en qué actividad andaba metido allá por el año 1933 nuestro ilustre escritor cuando comenzó la escritura de estos cuentos. El origen inmediato ha sido visto por Rivera, al que cita Servelli43, de este modo:

Refiriéndose expresamente a los cuentos incluidos posteriormente en Historia Universal de la infamia, además de la habitual puesta en correlación de procedimientos formales y lenguaje cinematográfico ("[...] la selectiva 'diferencia' de planos, el 'montaje' de imágenes y secuencias, la 'fragmentación' del cuadro, la 'valoración' de los detalles, etc."), Rivera realiza una vuelta de tuerca más al remitir estos mecanismos narrativos tanto "a las tiránicas exigencias de brevedad

\footnotetext{
42 Estas narraciones de Borges fueron publicadas por el editor catalán Juan Torrondell (promotor de clásicos de la literatura y la filosofía en tiradas masivas) por el sello Tor. Este libro de Borges fue su primera incursión en la narrativa: llevaba una impactante faja que llevaba por título: "Toda la escoria del mundo".

43 Servelli (2002-2003: 90).
} 
y expresividad que suele demandar el periodismo", como a la historieta, en cuanto a la utilización de cierta óptica fragmentadora, reductora y selectiva. Las dos asociaciones responden claramente al contexto de publicación de las falsas notas biográficas, y posibilitan otra entrada para la lectura de los cuentos.

Los antecedentes no los lleva todos consigo Borges en la creación ex novo de esta forma de narrar que está inspirada, grosso modo, en Cervantes ${ }^{44}$, pero concretamente en Herbert Asbury (1889-1963), cronista de la mala vida urbana que publicó una historia bastante leída en la revista American Mercury (dirigida por H. L. Mencken): una prostituta llevaba a fornicar a sus clientes protestantes a un cementerio católico y a sus clientes católicos a un cementerio protestante. El escándalo fue de tal magnitud que convirtió a Asbury en una estrella de la prensa, lo que le permitió desde entonces escribir con comodidad sus libros sobre el delito en los Estados Unidos, entre ellos Gangs of New York ("Bandas de Nueva York"), The Gangs of Chicago ("Las bandas de Chicago") y The Barbary Coast ("La costa de Berbería"), este último sobre el crimen en San Francisco... Textos que conoció Borges. Pero es muy importante, a pesar de estas voces que siempre tengamos en cuenta en Borges el valor de lo apócrifo, como elemento que provoca la credibilidad de su

\footnotetext{
${ }^{44}$ D’Angelo, B. (2006): “Borges admiraba la capacidad imaginativa de Cervantes, y loaba, sobre todo, su habilidad de insertar, en una realidad aparentemente seca, árida, despojada de cualquier realismo que presuma copiar lo que se observa, sueños, aventuras, fantasías que ennoblecen la percepción de lo visible (...) Esta magia es a la vez efecto y artificio de la literatura. (...) Borges descubre que, a pesar de sus debilidades estilísticas, de estas patéticas vanidades que creen en la perfección humana, la propuesta cervantina puede sobrevivir al fuego de la inmortalidad: son el diálogo sincero y la tierna amistad que vinculan a Cervantes con su Quijote que, fuera de psicologismos presuntuosos y jadeantes, permiten que el autor 'padezca' (en su sentido etimológico y evangélico de 'pasión') con su personaje, y el lector, gracias a una callada complicidad, reviva eternamente las aventuras del héroe, como si soñador y soñado se unieran en la función capital del lector, es decir, la magia de hacer 'experiencia' de la ficción (...)Borges mismo aprendió de Cervantes, principalmente, dos enseñanzas. La primera es haberle perdido el respeto (creativamente) a los libros, es decir a su capacidad de glosarlos, parodiarlos y desatar toda su vertiente lúdica. La segunda es su identificación con Quijano y su soledad".
} 
escritura, que como recuerda Aguinis tenía la singularidad de las muñecas matrioskas:

Perpetraba el relato de otro relato, la reflexión de otra reflexión, con máscaras y símbolos, exageraciones y subterráneo humor. Desafía las clasificaciones convencionales de la literatura. Incluso la realidad es a veces envuelta en colores que la tornan irreal, con lo cual se disuelven las fronteras entre vigilia y sueño. El sardónico autor juega con la presunción de que reporta hechos históricos, pero dispara hacia niveles imaginarios sin que el lector advierta cuándo lo hace ${ }^{45}$.

\section{Recuerda el periodista Abós que}

en 1933 Natalio Botana, director-propietario de Crítica46, decidió incorporar un suplemento literario que compitiese con los prestigiosos rotograbados dominicales de La Prensa y La Nación (éste, dirigido por Eduardo Mallea). Convocó para llevar a cabo el proyecto a un periodista de la casa, Ulyses Petit de Murat, y a un escritor de treinta y cuatro años, Jorge Luis Borges (Costa, 2005).

que colaborará en Crítica Revista Multicolor, los sábados, corrigiendo originales, traduciendo y adaptando textos. En consecuencia, se puede afirmar como han dicho otros, que probablemente deba a Natalio Botana el que se lanzase a escribir cuentos (un género en el que no estaba seguro) porque éste le exigió publicar uno cada quince días para no perder el empleo. Estas ideas también aparecen corroboradas por Ivan Carlo, que nos habla de un cierto escándalo en la época por parte de esta revista que no era bien vista por los periodistas serios por su carácter sensacionalista:

\footnotetext{
${ }^{45}$ Aguinis (2006).

${ }^{46}$ Costa (2005). Dice René de Costa que el periódico Crítica era "un tabloide recién fundado cuyos parámetros intelectuales eran los deportes y el sensacionalismo (...) Los lectores de esta publicación serían lo que Henry Mencken llamaba la 'booboisie' y Borges hizo para ellos una serie de viñetas cómicas de personajes extravagantes, una galería de piratas, estafadores, canallas y gánsteres -hay que pensar que estamos en los años 30- todo bajo el rótulo de Historia universal de la infamia. Después de publicar media docena de estas historias, unas reales, otras ficticias, Borges se aburrió del proyecto e interrumpió su colaboración en Crítica, pero decidió publicar las historias en un delgado volumen con el mismo título rimbombante de Historia universal de la infamia, en 1935".
} 
A revista, belamente ilustrada, misturava literatura com jornalismo marrom na tentativa de agradar ao paladar da massa. Borges, convidado a colaborar, teve de adequar sua prosa a essa demanda. O resultado foi uma mistura de jornalismo con literatura, de fatos reais como imaginarios, ao estilo deo que fazia Edgar Allan $\mathrm{Poe}^{47}$.

\section{Comenzó a escribir también cuentos}

acuciado por los cierres semanales y por los diagramadores, que lo obligaban a cortar textos, a veces, jay!, los propios. En el número 1 de la Revista Multicolor inauguró con el cuento "El espantoso redentor Lázarus Morell" una serie de desmesurado título: Historia universal de la infamia; luego tocó el turno a "Eastman, el proveedor de iniquidades", y así, semana tras semana, fue completando su galería de asesinos, bandoleros, estafadores y criminales, en historias que pasaban vertiginosamente de Arkansas a Five Points, de la antigua China al barrio porteño de Villa Rica ¿De dónde extraía los argumentos? Borges 'refritaba', aderezándolas con su escritura ya entonces inimitable, las fuentes más diversas (Abós, 2003).

Por tanto, Borges lleva a cabo estos escritos gracias a una coyuntura que le impele a ello y tomando como punto de partida lo que ya había escrito Asbury referido a Estados Unidos. Ahora bien, Borges, conocedor de la tradición literaria española, fundamentalmente de Cervantes y sus aportaciones estilísticas, así como de las vanguardias (su primera etapa es ultraísta y su consideración de alumno de Cansinos Assens así lo acredita) aporta en su invención indefectiblemente la restauración, renovación o recreación literaria (el 'refrito' al que se refería Abós) creando un nuevo producto que ya no se parecerá en nada a los modelos precedentes. Igual que había hecho Cervantes con los libros de caballerías, creó una desproporción, una estética nueva que es una superación del discurso objetivo y realista que llegaba prácticamente desde el Arte poética de Aristóteles. Y para ello tiene unos claros antecedentes: Stevenson ${ }^{48}$, Chesterton, los films de Von Sternberg, la biografía de Evaristo Carriedo...

\footnotetext{
${ }^{47}$ Véase Carlo: la referencia bibliográfica completa se halla en Bibliografía, al final del estudio.

${ }^{48}$ Balderston (véase Bibliografía) afirmaba que "de Stevenson proviene la tendencia a economizar y la exageración en los personajes, el anhelo de 'visibilidad' y de escenas sensacionales y la obsesión por ciertas variedades de pícaros". Es interesante en este sentido la obra de P. Champion, "Marcel Schwob et Stevenson", Revue Universelle, 10 de diciembre de 1926, págs. 528-541.
} 
Pero también varios críticos descubrieron que un libro no mencionado por Borges en el prólogo, Vies imaginaires (Vidas imaginarias) de Marcel Schwob, tienen bastantes semejanzas con el libro de Borges. En ese libro Schwob mezcla la biografía, la historia, la arqueología y la poesía para crear una voz literaria propia ${ }^{49}$. También tendría mucha importancia e influyó sobre manera el libro de Richard Garnett, El ocaso de los dioses, como recordaba María E. Vázquez (2005). También nos recuerda Balderston ${ }^{50}$ que «los cuentos tienen aproximadamente la misma extensión, muestran

49 Por ejemplo, entre las vidas imaginarias a las que Schwob dedicó su atención se encuentran las de "El capitán Kid, pirata", "Walter Kennedy, pirata iletrado", "El mayor Stede Bonet, pirata por humor", "MM. Burke et Hare, asesinos". Schwob, M.: "Préface" en Vies imaginaires http://www.marcel-schwob.org/Oeuvres/170/vies-imaginaires (Consultado el 4 de junio de 2006) desarrolla algunas ideas muy interesantes sobre la concepción en torno a lo biográfico que influyeron sin duda en estos personajes 'históricos' a los que alude Borges: “Les idées des grands hommes sont le patrimoine commun de l'humanité: chacun d'eux ne posséda réellement que ses bizarreries. Le livre qui décrirait un homme en toutes ses anomalies serait une œuvre d'art comme une estampe japonaise où on voit éternellement l'image d'une petite chenille aperçue une fois à une heure particulière du jour (...) L'art du biographe consiste justement dans le choix. Il n'a pas à se préoccuper d'être vrai; il doit créer dans un chaos de traits humains. Leibnitz dit que pour faire le monde, Dieu a choisi le meilleur parmi les possibles. Le biographe, comme une divinité inférieure, sait choisir parmi les possibles humains, celui qui est unique. Il ne doit pas plus se tromper sur l'art que Dieu ne s'est trompé sur la bonté. Il est nécessaire que leur instinct à tous deux soit infaillible. De patients démiurges ont assemblé pour le biographe des idées, des mouvements de physionomie, des événements. Leur œuvre se trouve dans les chroniques, les mémoires, les correspondances et les scolies (...) L'art du biographe serait de donner autant de prix à la vie d'un pauvre acteur qu'à la vie de Shakespeare..."

50Sigue afirmando el profesor Balderstone que “Schwob declara en el prólogo que los historiadores tienden lamentablemente a dejarnos en la ignorancia sobre ciertos pormenores que ayudan a nuestra comprensión de las figuras históricas - las cáscaras de naranja que el Dr. Johnson llevaba en los bolsillos, por ejemplo - mientras, por lo contrario, 'El arte se opone a las ideas generales, describe lo individual, desea lo único. No clasifica; desclasifica', y más adelante: El arte del biógrafo consiste precisamente en la selección. No debe preocuparse por ser verdadero; debe crear un caos con rasgos humanos. Leibniz dice que Dios, para crear el mundo, eligió lo mejor entre lo posible. El biógrafo, como una divinidad inferior, sabe elegir lo que es único entre los posibles humanos". 
igual interés en pillos de toda clase y presentan a los personajes de una manera deliberadamente artificiosa».

Quizá el defecto achacable a estas historias resida en su capacidad de simplificación. Esta conversión en entidades literarias y el hecho de que el escritor imbuido por su espacio escénico y por sus concepciones sobre la realidad guillotine aspectos cruciales en detrimento de la verosimilitud o de la comprensión total de la historia creando una especie de sucedáneos de existencias literaturizadas, que son un modelo de acción y de selección, pero también de reducción. Un hecho que se le criticaba también a Stevenson, al haber simplificado excesivamente y haber reducido a su mínima expresión la complejidad de la vida real. Y Borges era consciente de ello cuando decía en el prólogo ${ }^{51}$ que se abusaba en ellos de algunos procedimientos como «la reducción de la vida entera de un hombre a dos o tres escenas». Pero tanto Stevenson como Borges coinciden en que sus obras son tomadas de los libros y nunca son recreaciones del original. Se trata de aventuras siempre librescas al igual que Cervantes realiza una recreación libresca (en cierto modo) con el Quijote, con todas las aportaciones y novedades a las que nos referimos en su momento. Borges, no obstante, se acerca muchos más a Cervantes, del que ha captado su tono burlón y caricaturesco, hecho que no acaece en Stevenson. Pero el arte literario, la creación literaria, en definitiva, es libresca, todo son palabras y la conformación de una serie de convenciones entre lector y escritor, y las necesidades mecánicas de uno u otro arte determinan un producto más artificioso o convincente. En este caso Historia universal de la infamia, aun en sus reducciones vitales, es un producto convincente. Como recuerda Tomás Eloy Martínez (2005):

Jorge Luis Borges, que comenzó ejercitándose en las ficciones verdaderas porque desconfiaba de su propia imaginación -como Stendhal-, declara en la Autobiografía que sus primeros "cuentos legítimos asumían la forma de falsificaciones y seudo ensayos". "En Historia universal de la infamia -escribe- no quise repetir lo que hizo Marcel Schwob en sus Vidas imaginarias. Schwob inventó biografías de hombres reales sobre los que hay escasa o ninguna información. Yo, en cambio, leí sobre personas conocidas, y cambié y deformé

\footnotetext{
${ }^{51}$ Borges (1980: 147).
} 
deliberadamente todo a mi antojo". Uno de los propósitos de aquellos ejercicios era complacer al público. "Esos relatos -advierte Borges- estaban destinados al consumo popular en las páginas de Crítica y eran deliberadamente pintorescos.

\section{En cualquier caso, sí podemos afirmar con Balderston que}

un estudio cuidadoso de los cuentos de infamia demuestra que, si no hay una "emanación personal", habría al menos un principio ordenador impuesto a los cuentos tales como fueron contados y vueltos a contar en las fuentes publicadas, una innovación estilística y técnica estrechamente relacionada con la amanerada artificialidad de Stevenson, Chesterton y Stemberg. Muy a menudo los cuentos difieren de sus fuentes por la introducción o exageración de leitmotivs - atributos que se adhieren como adjetivos a los personajes (como Borges dice en "El muerto", OC, 548) tales como las mascotas de Eastman, la obsesión del Profeta velado por las máscaras, los espejos y la ceguera, o el insistente uso de los dobles en el cuento sobre el caso Tichborne, “El impostor inverosímil Tom Castro"52.

En "Magias parciales del Quijote", perteneciente a su libro El hacedor (1960) decía Borges que "en 1833 Carlyle observo que la historia universal es un infinito libro sagrado que todos los hombres escriben y leen y tratan de entender, y en el que también los escriben"53, y quizá esta gran metáfora de Carlyle sea la que siga Borges al escribir la Historia universal de la infamia, un libro en el que también en cierto modo todos somos héroes y villanos, todos somos los escribanos y los lectores del mismo.

\section{Como resumen nos parecen interesantes estas palabras de Servelli ${ }^{54}$ :}

Los cuentos de Historia universal de la infamia priorizan los lineamientos argumentales (la trama) por sobre la construcción exhaustiva del personaje literario. Este último resulta bocetado mediante la presentación circunstancial de algunos rasgos aislados: Monk Eastman recorriendo su imperio neoyorkino con una paloma al hombro, el negro Bogle detenido en cada bocacalle recelando el cruce fatal, la crencha rojiza de Billy the Kid sobresaliendo en un conventillo plagado de negros, Kuranosuké, el consejero, revolcado en un vómito mientras pergeña la venganza. El campo semántico negativo señalado en la serie de citas con que pretendimos delinear una teoría del personaje cinematográfico (según Borges) es

\footnotetext{
52 Balderston, "Precursor", op. cit.

${ }^{53}$ Borges (1980: 175).

${ }^{54}$ Servelli (2002-2003).
} 
perfectamente aplicable a este conjunto de personajes: disfrazados, caricaturales, irreales. La elección y presentación de los personajes biografiados en HUI no apunta a una familiarización con el lector sino, por el contrario, a un extrañamiento, de manera tal que la única coherencia posible sólo pueda darse en la máscara. Los cambios de nombres, los nombres falsos, la ausencia de 'efigies', la impostura, y el enmascaramiento dominan los relatos. Señala Molloy en Las letras de Borges, que "el personaje de Borges rara vez es persona, si actante diseminado en el texto", no hay un personaje que encarne en una situación que dé cuenta del texto, sino que hay en los cuentos una 'situación plural', la organización de un argumento.

\section{BIBLIOGRAFÍA}

Abós, A. (2003): “Antes que Scorsese, Borges”, La Nación, 7 de febrero.

Aguinis, M. (2006):“Borges enamora en Washington” en La Nación, 26 de mayo.

Annick, L. (1997): Jorge Luis Borges: œuvre et manœuvres, París.

Balderston, D.: "El precursor velado: R. L. Stevenson en la obra de Borges", URL:<http://www.uiowa.edu/borges/bsol/db3.shtml (Consultado el 8 de enero de 2007).

Barros-Lémez, A.:"La infamia de Borges. Apuntes para otra historia posible”, http://letras-uruguay.espaciolatino.com/barros/las_infamias_de_

borges.htm. (Consultado el día 2 de septiembre de 2006).

Borges, J. L. (1980): Historia universal de la infamia, en Prosa completa I, Barcelona, Bruguera.

Borges, J. L. (1980): “Magias parciales del Quijote" en El hacedor, Prosa completa II, Barcelona, Bruguera.

Borges, J. L. (1962): “Sobre Chesterton" en Otras Inquisiciones, Prosa completa II, Barcelona, Bruguera.

Borges, J. L. (1980): "Prólogo a la edición de 1954" en Prosa completa I, Barcelona, Bruguera.

Borges, J. L. (1980): “La supersticiosa ética del lector” en Prosa completa I, Barcelona, Bruguera.

Borges, J. L. (1980): "La duración del infierno" en Prosa completa I, Barcelona, Bruguera. 
Carlo, I.: "Idéias de Jeca-Tatu. Borges sensacionalista" www.ivancarlo.blogspot.com L2006_11_01_archive.html (Consultado el día 4 de julio de 2006).

Cordua, C.: “Borges y los servicios de la palabra”, Borges Studies Online. On line. J. L. Borges Center for Studies \& Documentation, URL: <http://www.uiowa.edu /borges/bsol/cordua.shtml. (Consultado el día 3 de octubre de 2006).

Costa, R. de (2005): “De cómo Borges escribe para divertir", La Raza, 17 de julio.

D’Angelo, B. (2006): “Borges y las magias del Quijote” en http://www.interletras.com.br., vol. 1, núm. 5, julio-diciembre.

Gamerro, C.: “Borges y los anglosajones” http://www.udesa.edu.ar/files/Events Larchivos/Gamerro-Borges-y-los\%20anglosajones.pdf (Consultado el día 19 de diciembre de 2006).

Gargan, E. A. (1986): “Jorge Luis Borges, a master of fantasy and fable, is dead”, New York Times, June 15.

Giordano, A.: "La creación de una obra" http://www.uiowa.edu/borges/vb4 Lgiordano.htm. (Consultado el día 16 de septiembre de 2006).

Glantz, M.: “Borges: ficción e intertextualidad”, http://www.elortiba.org/borges.

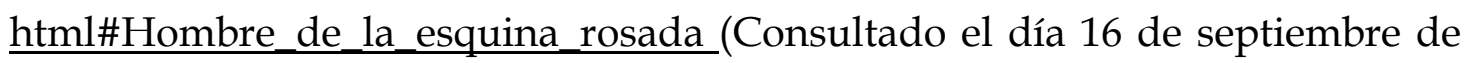
2006).

Martínez, T. E. (2005): “Ficciones verdaderas" en Letras Libres, julio. URL: <http://www.revistasculturales.com/articulos/91/letras-libres/382/4/ ficciones-verdaderas-html (Consultado el día 16 de marzo de 2006).

Midence, C.: “La imagen simbólica en Jorge Luis Borges: una aproximación a su propia realidad", URL:<http://www.grupoese.com.ni/1999/bcultural/112/ imagen112.htm (Consultado el 19 de septiembre de 2006).

Ruiz Pérez, P. (1986): “Borges, hacedor de ficciones. Una guía del laberinto”, Cuenta y Razón, 25.

Quesada, R. (1999): "Paul le Man. La lección del maestro" en La Jornada Semanal de New York Review of Books, 22 de agosto.

Ramírez, S. (1990): “Primeras letras con Borges" en Encuentro Borges y yo, Buenos Aires, Argentina, 8-11 de junio. 
Rey, E.: "Polifonía y contrapunto en la narrativa de Jorge Luis Borges" http:/ / www.lehman.crit 04.htm (Consultado el día 13 de diciembre de 2006).

Rey Beckford, R.: "Jorge Luis Borges: el sentido de la violencia" URL:<http:// www.lehman.cuny.edu/ciberletras/v1n1/crit_05.htm. (Consultado el día 8 de agosto d e 2006).

Schwob, M.: “Préface” en Vies imaginaires, http://www.marcel-schwob.org/Oeuvres L170/vies-imaginaires (Consultado el 4 de junio de 2006).

M. F. Servelli, “Mirando al sesgo: el cine en el texto borgeano” Everba, 2002-2003, págs. 81-96.

Spielmann, E. (2005): “Borges y Fuentes, autores y lectores del Quijote, a propósito de un homenaje en el IV centenario", Revista de Crítica Literaria Latinoamericana, año XXXI, 62.

Tedio, G.: "El relativismo de las visiones en la narrativa de Jorge Luis Borges" http://www.ucm.es/info/especulo/numero20/relativi.html. (Consultado el día 3 de noviembre de 2006).

Toro, A. del (1993): “Cervantes, Borges y Foucault: la realidad como viaje a través de los signos", conferencia, en Ibero-Amerikanischen Forschungsseminar de la Universidad de Hamburgo, 8 de enero. Ha sido ya publicado en alemán y en una versión bastante más breve en Zeitschrift für Ästhetik und Allgemeine Kunstwissenschaft 2, 39 (1994).

Vázquez, M.E. (2005): “Se lanza el primer libro de relatos de Borges”, La Nación.com, 28 de agosto. 